\title{
DIVERSITY OF CULTURABLE MODERATELY HALOPHILIC BACTERIA PRODUCING EXTRACELLULAR HYDROLYTIC ENZYMES FROM MARINE SEDIMENTS
}

\author{
DIVERSIDADE DE BACTÉRIAS CULTIVÁVEIS MODERADAMENTE \\ HALOFÍLICAS QUE PRODUZEM ENZIMAS HIDROLÍTICAS \\ EXTRACELULARES DE SEDIMENTOS MARINHOS
}

\author{
Shiping WEI; Beibei LIU; Hongpeng CUI; Rui FAN; Ce GUO; Mingxue SUN \\ School of Marine Sciences, China University of Geosciences, 29 Xueyuan Rd., Haidian District, Beijing 100083, China. \\ weishiping@cugb.edu.cn
}

\begin{abstract}
A total of 114 moderately halophilic bacteria were isolated from marine sediment environments. The isolates are belonged to 23 species based on the $16 \mathrm{~S}$ rRNA sequence analysis. 63, 52, 47, 57, 74, 15 and 4 isolates are able to produce protease, amylase, lipase, pectinase, pulluanase, xylanase, cellulase, respectively. Combined hydrolytic enzyme activity analysis show that 15 strains present 1 hydrolytic activity, 32 strains present 2 hydrolytic activities, 21 strains present 3 hydrolytic activities, 26 strains present 4 hydrolytic activities, 11 strains present 5 hydrolytic activities and 2 strains present 6 hydrolytic activities. Hydrolase activities are widely distributed in a variety of species. The highest rates for production of protease, amylase, lipase, pectinase, pullanase, xylanase and cellulase were observed in species of B. baekryungensis, Hallobacillus sp., B. pumilus, B. megaterium or P. chungwhensis, B. amyloliquefaciens, B. pumilus, B. baekryungensis, respectively. However, the higher activities of protease, pectinase and pulluanase are frequently produced by the species of Halomonas sp. B. amyloliquefaciens or P. chungwhensis, and Vibrio sp. respectively. This investigation show that the diversity of halophilic bacteria from marine sediments could serve as a potential source of hydrolytic enzymes for industrial applications.
\end{abstract}

KEYWORDS: Moderately halophilic bacteria. Hydrolytic enzyme. Marine sediment.

\section{INTRODUCTION}

Halophilic microorganisms have attracted considerable interest due to their considerable capability of producing compounds with great industrial potential (MARGESIN AND SCHINNER 2001; VENTOSA et al. 1998). One of the most important biotechnological applications of these halophilic bacteria is focused on their production of diverse extracellular enzymes, such as amylase, lipase, caseinase, xylanase, inulinase, pectinase, cellulase, pullulanase, gelatinase, urease, glutaminase and asparaginase (MELLADO et al. 2004), as the bacteria have the desirable physiological properties of stability and solubility at high salt concentrations, which facilitate their use in the areas of food processing, feed additives, biomedical sciences and chemical industries (KULKARNI et al. 1999; NIEHAUS et al. 1999; PANDEY et al. 1999 and 2000; RAO et al. 1998).

Moderately halophilic bacteria usually are defined as a group of halophiles able to grow optimally in media containing $3-15 \% \mathrm{NaCl}$ (VENTOSA et al. 1998), which are widely distributed in various marine environments and have been frequently isolated from crystallizer ponds, saline soil, salt marshes and solar salterns (OREN et al. 2002). This study aimed to isolate moderately halophilic bacteria from marine sediments, and characterize their capabilities for producing different extracellular hydrolytic enzymes with a view to providing valuable information about their potential utilization in industrial scale process.

\section{MATERIAL AND METHODS}

Isolation of moderately halophilic bacteria and culture conditions

Marine sediments of tidal zones were collected with aseptic methods. One gram of each sample was suspended in autoclaved sea water and made an appropriate dilution. One hundred milliliter of each diluted sample was plated on the isolation medium containing (per liter): casamino acid $7.5 \mathrm{~g}$, yeast extract $10 \mathrm{~g}, \mathrm{MgSO}_{4} .7 \mathrm{H}_{2} \mathrm{O} 20 \mathrm{~g}$, trisodium citrate $3 \mathrm{~g}, \mathrm{KCl} 2 \mathrm{~g}, \mathrm{FeSO}_{4} .7 \mathrm{H}_{2} \mathrm{O} 1.6 \mathrm{mg}, \mathrm{NaCl} 100$ $\mathrm{g}$, agar $15 \mathrm{~g}$, pH 7.2-7.4. The plates were incubated at $30^{\circ} \mathrm{C}$ for $10 \mathrm{~d}$. Basted on the colony characteristics, different bacteria were picked up and inoculated into liquid medium containing 5\% $\mathrm{NaCl}$. Pure culture of each isolate was stored in $20 \%$ glycerol at $-80^{\circ} \mathrm{C}$ for further identification and characterization.

Identification of the isolates 
Extraction of bacterial genomic DNA, amplification and sequencing of 16S rRNA gene sequences were performed as WEI et al. (2015) described. Preliminary identification was performed by BLAST search to suggest the closest relatives against GenBank database and a more precise identification was performed by phylogenetic analysis with type strains of the nearest neighbors. Isolates were regards as belonging to a species when sequence similarity with the species types strain was at least $97 \%$.

\section{Determination of extracellular hydrolytic enzyme activity}

Proteolytic activity of the isolates was screened and determined on the medium (per liter) containing skim milk $15 \mathrm{~g}$, yeast extract $2 \mathrm{~g}, \mathrm{NaCl}$ $100 \mathrm{~g}$, agar $20 \mathrm{~g}$. After incubation at $30^{\circ} \mathrm{C}$ for $5 \mathrm{~d}$, clear zones around the colonies appearing were taken as the evidence of protease producing strains.

The presence of amylolytic activity on plates was determined on the medium (per liter) containing starch $5 \mathrm{~g}$, yeast extract $2 \mathrm{~g}$, $\left(\mathrm{NH}_{4}\right)_{2} \mathrm{SO}_{4}$ $1.4 \mathrm{~g}, \mathrm{~K}_{2} \mathrm{HPO}_{4} 2 \mathrm{~g}, \mathrm{MgSO}_{4} .7 \mathrm{H}_{2} \mathrm{O} 0.2 \mathrm{~g}, \mathrm{NaCl} 100 \mathrm{~g}$, agar 20 g. pH 7.2. After incubation at $30^{\circ} \mathrm{C}$ for $5 \mathrm{~d}$, the plates were flooded with $0.3 \% \quad \mathrm{I}_{2}-0.6 \% \quad \mathrm{KI}$ solution; a clear zone around the growth colony indicates the positive strains which through of producing amylase to hydrolyse starch.

Lipolytic activity of the isolates was detected on Tributyrin medium (per liter) containing beef extract $3 \mathrm{~g}$, peptone $10 \mathrm{~g}$, tributyrin $6 \mathrm{ml}, \mathrm{NaCl}$ $100 \mathrm{~g}$, agar $20 \mathrm{~g}$ (KHUNT; PANDHI 2011). The plates were incubated at $30^{\circ} \mathrm{C}$ for $5 \mathrm{~d}$. Colonies showing a surrounding clear zone were lipase producers.

Assay of pectinolytic activity by the method described by Rohban et al. (2009) on the medium (per liter) containing $\left(\mathrm{NH}_{4}\right)_{2} \mathrm{SO}_{4} 1.4 \mathrm{~g}, \mathrm{MgSO}_{4} .7 \mathrm{H}_{2} \mathrm{O}$ $0.2 \mathrm{~g}, \mathrm{~K}_{2} \mathrm{HPO}_{4} 2 \mathrm{~g}$, yeast extract $2 \mathrm{~g}$, pectin $5 \mathrm{~g}$, nutrient solution $1 \mathrm{ml} \quad\left(\mathrm{FeSO}_{4} \cdot 7 \mathrm{H}_{2} \mathrm{O} 5 \mathrm{mg} / \mathrm{l}\right.$, $\mathrm{MnSO}_{4} \cdot \mathrm{H}_{2} \mathrm{O} 1.6 \mathrm{mg} / \mathrm{l}, \mathrm{ZnSO}_{4} .7 \mathrm{H}_{2} \mathrm{O} 1.4 \mathrm{mg} / \mathrm{l}, \mathrm{CaCl}_{2}$ $2 \mathrm{mg} / \mathrm{l}), \mathrm{NaCl} 100 \mathrm{~g}$, agar $20 \mathrm{~g}$. After incubation at $30^{\circ} \mathrm{C}$ for $5 \mathrm{~d}$, the plates were flooded with $0.3 \% \mathrm{I} 2-$ $0.6 \% \mathrm{KI}$ solution; a clear zone around the growth colony was identified as the pictinase producing strains.

The method of detection of pullulanase activity was adopted by Rohban et al. (2009) and Ruben et al (1993) with modifications. The medium (per liter) was used as yeast extract $2 \mathrm{~g}$, pullulan $5 \mathrm{~g}$, $\mathrm{NaCl} 100 \mathrm{~g}$, agar $20 \mathrm{~g}$. After incubation at $30^{\circ} \mathrm{C}$ for $5 \mathrm{~d}$, the plates were flooded with $0.3 \% \mathrm{I}_{2}-0.6 \% \mathrm{KI}$ solution instead of $97 \%$ ethanol, a clear zone around the colonies was identified as the pullulanase activity produced by the strains.

Xylanase activity was detected using the medium (per liter) containing yeast extract $2 \mathrm{~g}$, peptone $5 \mathrm{~g}, \mathrm{MgSO}_{4} .7 \mathrm{H}_{2} \mathrm{O} 0.5 \mathrm{~g}, \mathrm{CaCl}_{2} 0.15 \mathrm{~g}$, xylan $10 \mathrm{~g}, \mathrm{NaCl} 100 \mathrm{~g}$, agar $20 \mathrm{~g}$. After incubation at $30^{\circ} \mathrm{C}$ for $5 \mathrm{~d}$, the plates were stained with $10 \mathrm{ml}$ $0.1 \%$ congo red solution for $20 \mathrm{~min}$, then drained of the dye, a clear zone around the colonies indicate the xylanase activity producers (KAKHKI et al. 2011; ROHBAN et al. 2009).

Cellulase activity of the cultures were screened on the medium (per liter) containing carboxy methyl cellulose (CMC) $5 \mathrm{~g}, \mathrm{NaNO}_{3} 1 \mathrm{~g}$, $\mathrm{K}_{2} \mathrm{HPO}_{4} 2 \mathrm{~g}, \mathrm{KCl} 1 \mathrm{~g}, \mathrm{MgSO}_{4} .7 \mathrm{H}_{2} \mathrm{O} 0.5 \mathrm{~g}$, yeast extract $2 \mathrm{~g}$, glucose $1 \mathrm{~g}, \mathrm{NaCl} 100 \mathrm{~g}$, agar $20 \mathrm{~g}, \mathrm{pH}$ 7.2. After incubation at $30^{\circ} \mathrm{C}$ for $5 \mathrm{~d}$, the plates were poured with $10 \mathrm{ml} 0.1 \%$ congo red solution and stained with the dye for $20 \mathrm{~min}$, then drained of the dye. A clear zone surrounding the colony shows the cellulase activity producing by the strains (KAKHKI et al. 2011; ROHBAN et al. 2009).

\section{RESULTS AND DISCUSSION}

\section{Isolation and identification of moderately halophilic bacteria}

A total of 114 strains were obtained which grew well on the media containing of $5 \%-15 \%$ $\mathrm{NaCl}$. 16S rRNA sequence analyses show that they are grouped into 23 species at a $97 \%$ sequence similarity threshold. Out of 114 isolates, 94 isolates $(82.5 \%)$ are Gram positive, while 20 isolates (17.5\%) are Gram negative. 17 species belong to the type of Gram positive bacteria with the dominance of Bacillus baekryungensis (15.8\%), Bacillus pumilus (12.3\%), Bacillus megaterium (10.5\%), Pontibacillus chungwhensis (12.3\%) and Halobacillus sp. (9.6\%), comparison of 6 species belong to the type of Gram negative bacteria with the dominance of Cobetia marina (8.8\%) (Table 1). The result is similar with Babavalian et al. (2013) reported that more Gram positive (61 isolates) than Gram negative (22 isolates) moderately halophilic bacteria were obtained from a largest hypersaline Playa in Iran for produce hydrolytic enzymes.

\section{Enzymatic activity of isolates}

Halophilic microorganisms have been investigated for their potential biotechnological applications in various fields, such as production of compatible solutes, biopolymers, enzymes, food biotechnology, and biological waste treatment (MARGESIN; SCHINNER 2001). Moreover, increasing concerns focus on the salt tolerant 
extracellular hydrolytic enzymes produced by moderately halophilic and halotolerant bacteria (MELLADO et al. 2004; VENTOSA et al. 1998; MORENO et al. 2013). Halophilic and halotolerant bacteria are an excellent source of enzymes exhibiting salt, $\mathrm{pH}$ and temperature tolerance (GOMEZ; STEINER 2004; SÁNCHEZ-PERRO et al. 2003).

In this study, seven extracellular hydrolytic enzyme activities were tested among the 114 isolates (Table 1). 107 isolates (93.9\%) are able to produce at least one of the hydrolytic activities, whereas 7 isolates $(6.1 \%)$ are unable to produce any of the tested hydrolytic activities. A total of 63 (49 Gram positive and 14 Gram negative), 52 (39 Gram positive and 13 Gram negative), 47 (41 Gram positive and 6 Gram negative), 57 (48 Gram positive and 9 Gram negative), 74 (60 Gram positive and 14 Gram negative), 15 (all Gram positive), 4 (all Gram positive) isolates are able to produce protease, amylase, lipase, pectinase, pulluanase, xylanase, and cellulase, respectively. Combined hydrolytic enzyme activities were detected and the results show that the isolates have diversities for enzyme production. Fifteen strains present one hydrolytic activity, 32 strains present 2 hydrolytic activities, 21 strains present 3 hydrolytic activities, 26 strains present 4 hydrolytic activities, 11 strains present 5 hydrolytic activities and 2 strains present 6 hydrolytic activities. Among the tested strains, Halobacillus sp. HNI111 and Halomonas sp. QD55 show the higher protease activity, B. amyloliquefaciens BDH11 and BDH27 present the higher amylase activities, $B$. megaterium HNS83 and B. pumilus BDH24, HNS77 and HNS81 present the higher lipase activities, $B$. amyloliquefaciens $\mathrm{BDH} 27$, B. cereus $\mathrm{HNI} 98$ and $P$. chungwhensis HNI96 show the higher pectinase activities, Vibrio sp. QD45 presents the higher pulluanase activity, B. pumilus HNS74 presents the higher xylanase activity, and $B$. amylolquefaciens BDH11 and HNI92 present the higher cellulase activities.

Our results show that the higher rates of production of protease, amylase, lipase, pectinase, and pulluanase, but much lower rates of xylanase and cellulase, are observed among these isolates. This is somewhat different from Rohban et al. (2009), who reported higher rates of production of amylase, lipase, protease, xylanase, and inulinase, but lower rates of pullulanase, pectinase, and cellulase production, among the halophilic isolates isolated from Howz Soltan Lake. We infer that this is due to the different strain species fostered by the different environments. Among the cultured strains, most of them present the combined hydrolytic activities and similar results to those reported by Rohban et al. (2009) and Sánchez-Porro et al. (2003).

Table 1. Hydrolytic enzyme activity of moderately halophilic isolates

Activity of hydrolytic enzymes (halo diameter, cm)

Species

$\begin{array}{ll}\text { Strain } & \text { Accession } \\ \text { number } & \text { number }\end{array}$

离

\begin{tabular}{lllllllllll}
\hline Gram-positive bacteria & & & & & & & & & & \\
& BDH9 & KF933630 & - & - & - & - & - & - & - \\
& BDH15 & KF933610 & - & - & - & - & 1.1 & - & - \\
& BDH25 & KF933620 & 0.4 & - & - & - & 0.7 & - & - \\
& QD35 & KF933691 & 1.2 & - & - & - & - & - & - \\
& QD37 & KF933693 & 1.0 & - & - & - & 0.4 & - & - \\
& QD40 & KF933716 & - & - & - & - & 1.6 & - & - \\
Bacillus baekryungensis & QD41 & KF933695 & - & - & - & - & 0.5 & - & - \\
& QD42 & KF933696 & - & - & - & - & 0.4 & - & - \\
& QD54 & KF933706 & - & 0.7 & 1.9 & - & 0.2 & - & - \\
& QD56 & KF933708 & - & - & 0.4 & 0.2 & 1.1 & - & - \\
& HNS72 & KF933669 & 0.4 & - & - & 0.2 & - & - & - \\
& HNS80 & KF933677 & 0.4 & - & 1.5 & 0.8 & 1.5 & - & - \\
& HNS82 & KF933679 & - & - & - & - & - & - & -
\end{tabular}


Diversity of culturable...

WEI, S. et al

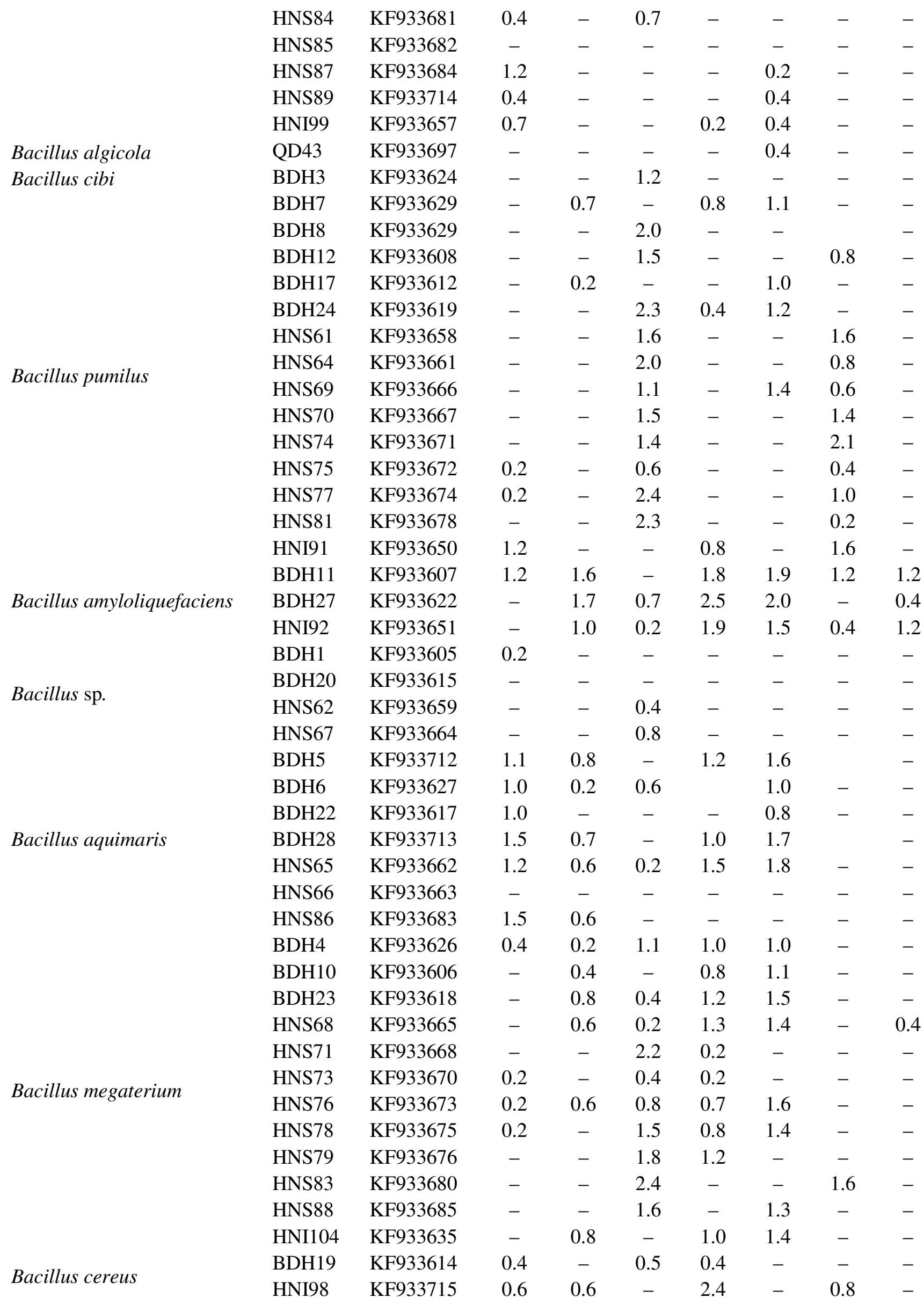


Diversity of culturable...

WEI, S. et al

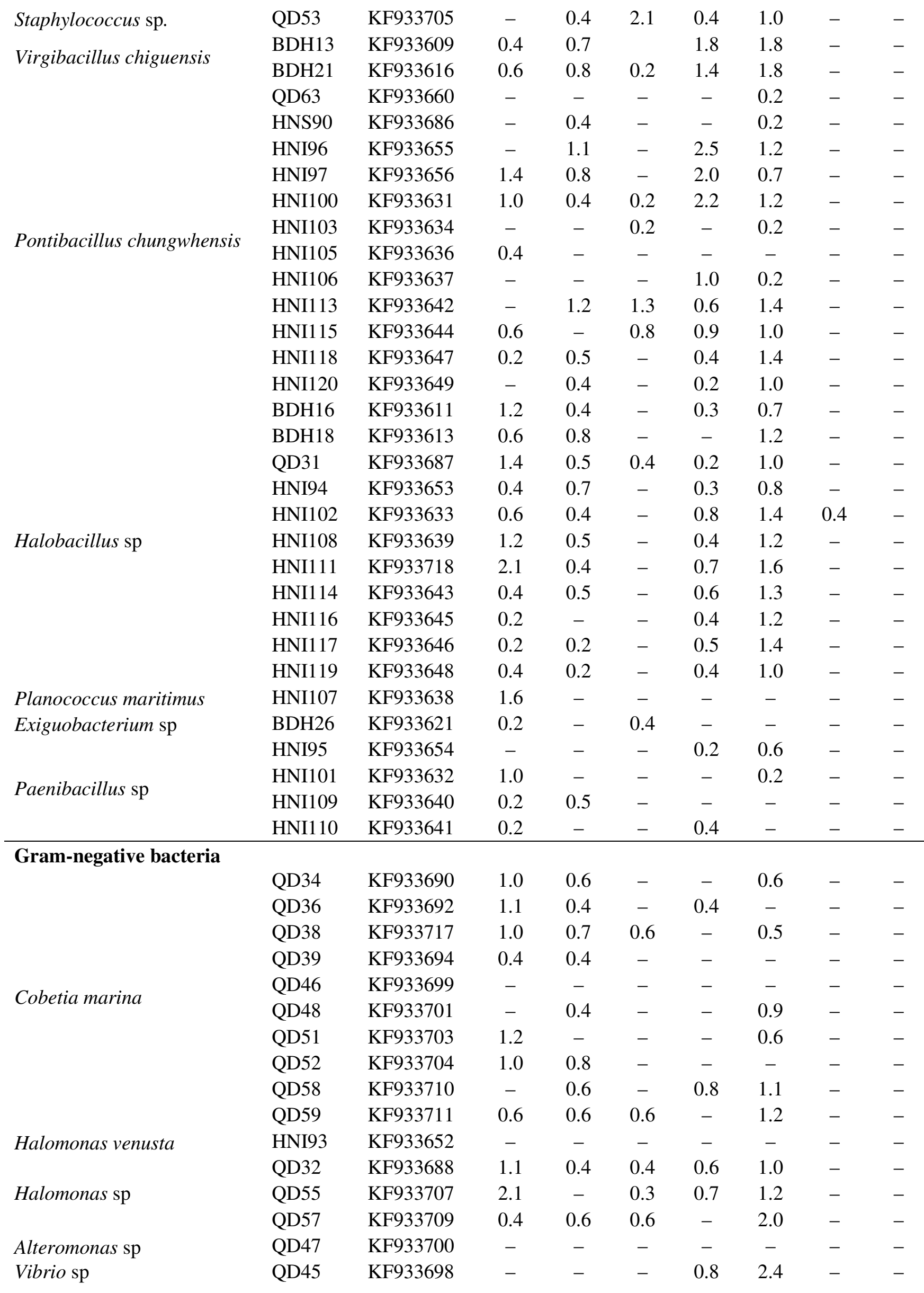




\begin{tabular}{llllcccccc} 
& QD49 & KF933702 & 0.8 & 0.5 & 0.2 & 0.2 & 0.4 & - & - \\
\multirow{2}{*}{ Photobacterium halotolerans } & BDH29 & KF933623 & 1.0 & 0.6 & - & 0.4 & 0.4 & - & - \\
\cline { 2 - 5 } Paracoccus homiensis & BDH30 & KF933625 & 0.8 & - & - & 0.2 & 0.5 & - & - \\
\hline
\end{tabular}

Note: After the incubation, diameters of each halo $\left(D_{h}\right)$ and each colony $\left(D_{c}\right)$ were measured. $\left(D_{h}-D_{c}\right)$ indicates the hydrolytic activity of each strain. - no hydrolytic enzyme activity was detected. We defined the hydrolytic activities greater than $1.2 \mathrm{~cm}$ for protease, 0.8 $\mathrm{cm}$ for amylase, $1.6 \mathrm{~cm}$ for lipase, $1.4 \mathrm{~cm}$ for pectinase, $1.6 \mathrm{~cm}$ for pulluanase, $0.8 \mathrm{~cm}$ for xylanase and $1.2 \mathrm{~cm}$ for cellulase as the higher enzymatic activity producing isolates.

\section{Enzymatic profiles of species}

Enzymatic profiles and the percentage for production of each enzymes associated with species are shown in Figure 1. A higher ratio of hydrolytic activity producing strains are frequently observed within a number of limited species. 18 species are able to produce protease, out of those species, $B$. baekryungensis (7.9\%) and Halobacillus sp. (9.6\%) show higher percentages of protease producing strains. However, higher percentages of higher proteolytic activity producing species are appeared in the species of $B$. aquimaris $(2.6 \%)$ and Halobacillus sp. (3.0\%) (Fig. 1A). 16 species are able to produce amylase. $8.8 \%$ of strains belonging to Halobacillus sp. are able to produce amylase, which is greater than all other species. Whereas higher percentages of higher amylolytic activity producing species are appeared in the species of $B$. amyloliquefaciens $(2.6 \%)$ and $P$. chungwhensis (2.6\%) (Fig. 1B). 16 species are able to produce lipase. B. pumilus $(9.7 \%)$ and B. megaterium $(8.7 \%)$ show the higher percentage of producing lipase, however no higher lipolytic activity producing strains are observed in the specie of $B$. megaterium. B. pumilius $(5.3 \%)$ show the higher percentage of higher lipolytic activity producing strains (Fig. 1C). 17 species are able to produce pectinase. $B$. megaterium $(8.8 \%)$ and Halobacillus sp. (8.8\%) show the higher percentage of producing pectinase, however no higher pectinolytic activity producing strains were observed in this two species, and higher percentages of higher pectinolytic activity producing strains were observed in the species of $B$. amyloliquefaciens $(2.6 \%)$ and $P$. chungwhensis (2.6\%) (Fig. 1D). 16 species are able to produce pullulanase. $B$. baekryungensis (10.5\%), $P$. chungwhensis $(9.7 \%)$ and Halobacillus sp. (9.7\%) show the higher percentage of producing pullulanase, and all the higher pulluanase activity producing strains are belonged to the species of $B$. aquimaris (2.6\%) (Fig. 1E). 5 and 2 species are able to produce xylanase and cellulose respectively (Fig.
$1 \mathrm{~F}$ and Fig. 1G). Xylanase production was also found to be limited to species of $B$. algicola, $B$. pumilus, B. amyliliquefaciens, B. megaterium, $P$. chuangwhensis and Halobacillus sp., and the higher percentage of producing xylanase is $B$. pumilus $(8.8 \%)$ (Fig. 1F). When compared with other enzymes, cellulose producing species is only associated with the two species of $B$. amyloliquefaciens (2.6\%) and B. megaterium (0.9\%) (Fig. 1G).

Moderately halophilic bacteria producing protease, amylase, lipase, pectinase, pulluanase and cellulase are widely distributed in the marine sediment environments. The highest rates for production of protease, amylase, lipase, pectinase, pulluanase, xylanase and cellulase are members of B. baekryungensis, Hallobacillus sp., B. pumilus, $B$. megaterium or $P$. chungwhensis, $B$. amyloliquefaciens, $B$. pumilus, and $B$. baekryungensis, respectively (Fig. 1). Rohban et al. (2009) reported that most amylase, DNase, and lipase producers are members of the genera Oceanobacillus, Halomonas, and Gracilibacillus respectively. Cellulase producers were detected among members of Gracilibacillus, Virgibacillus and Halobacillus. Kakhki et al. (2011) reported that under their conditions Halorubrum is the predominant genus showing the highest rates of amylase, lipase, pullulanase, inulinase and DNase production. Our data is much more similar to the results reported by Berrada et al. (2012), in which Bacillus is the predominant genus showing the higher production rates for amylase, lipase, DNase, protease and cellulase. It is interesting that higher average rates for production of the enzymes by a certain species do not necessarily mean that the higher enzyme-producing activity belonged to a strain from the same species. 


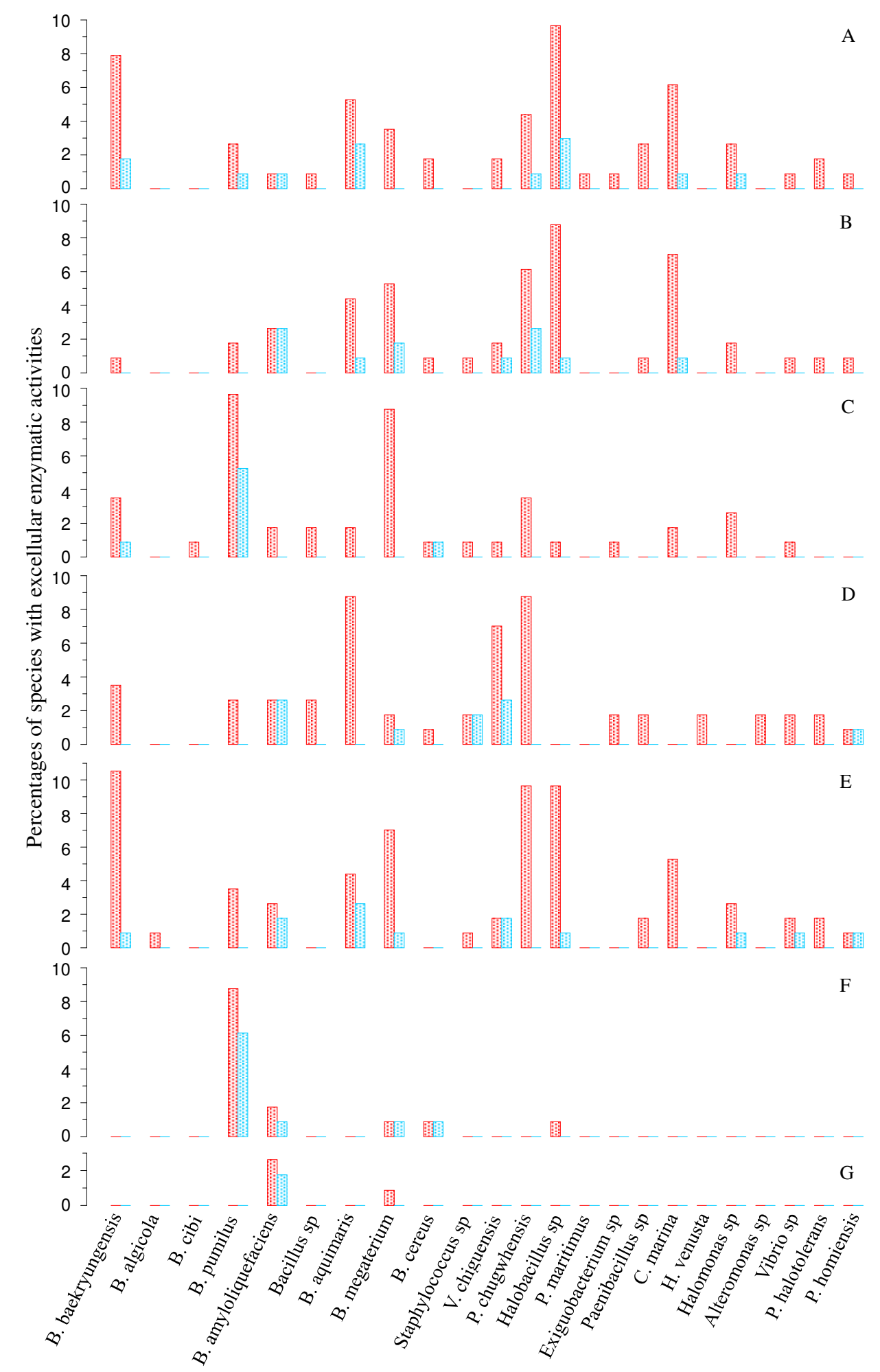

Figure 1. Enzymatic profiles of the isolates and comparison of the percentage for production of each enzymes among the strains. A, Protease; B, Amylase; C, Lipase; D, Pectinase; E, Pullulanse; F, Xylanase; G, Cellulase. Red columns indicate the percentage of species able to produce hydrolytic enzymes, blue columns indicate the percentage of species able to produce higher enzymatic activity. 


\section{CONLUSIONS}

We isolated 114 moderately halophilic bacteria from marine sediments, which comprising of 94 Gram positive bacteria and 20 Gram negative bacteria.

A total of 107 isolates are able to produce at least one of the hydrolytic activities. Most of them present the combined hydrolytic activities including of protease, amylase, lipase, pectinase and pulluanase, and only 15 and 4 isolates present xylanase and cellulose activities respectively.

The higher average rates for production of the enzymes by a certain species is inconsistent with the higher enzyme-producing activity belonged to the same species. Both of them are limited to a few different species.

RESUMO: Um total de 114 bactérias moderadamente halofílicas foram isoladas de ambientes de sedimentos marinhos. Os isolados pertencem a 23 espécies com base na análise da sequência 16S rRNA. 63, 52, 47, 57, 74, 15 e 4 isolados são capazes de produzir protease, amilase, lipase, pectinase, pululanase, xilanase, celulase, respectivamente. A análise da atividade enzimática hidrolítica combinada mostra que 15 cepas apresentam 1 atividade hidrolítica, 32 cepas apresentam 2 atividades hidrolíticas, 21 cepas apresentam 3 atividades hidrolíticas, 26 cepas apresentam 4 atividades hidrolíticas, 11 cepas apresentam 5 atividades hidrolíticas e 2 cepas apresentam 6 atividades hidrolíticas. Atividades de hidrolase são amplamente distribuídas em uma variedade de espécies. As maiores taxas de produção de protease, amilase, lipase, pectinase, pululanase, xilanase e celulase foram observadas em espécies de B. baekryungensis, Hallobacillus sp., B. pumilus, B. megaterium ou P. chungwhensis, B. amyloliquefaciens, B. pumilus, B. baekryungensis, respectivamente. No entanto, as atividades mais elevadas de protease, pectinase e pululanase são freqüentemente produzidas pelas espécies de Halomonas sp. B. amyloliquefaciens ou P. chungwhensis e Vibrio sp. respectivamente. Esta investigação mostra que a diversidade de bactérias halofílicas de sedimentos marinhos pode servir como uma fonte potencial de enzimas hidrolíticas para aplicações industriais.

PALAVRAS-CHAVE: Bactérias moderadamente halofílicas. Enzima hidrolítica. Sedimento marinho.

\section{REFERENCES}

BABAVALIAN, H.; AMOOZEGAR, M. A.; POURBABAEE, A. A.; MOGHADDAM, M. M.; SHAKER, F. Isolation and identification of moderately halophilic bacteria producing hydrolytic enzymes from the largest hypersaline Playa in Iran. Microbiology, v. 82, n. 4, p. 466-474, 2013.

http://doi.org/10.1134/S0026261713040176

BERRADA, I.; WILLEMS, A.; VOS, P. D.; EI-FAHIME, E.; SWINGS, J.; BENDAOU, N.; MELLOUL, M.; AMAR, M. Diversity of culturable moderately halophilic and halotolerant bacteria in marsh and two salterns a protected ecosystem of Lower Loukkos (Morocco). African Journal of Microbiology Research, v. 6, n. 10, p. 2419-2434, 2012. http://doi.org/10.5897/AJMR-11-1490

GOMEZ, J. AND STEINER, W. The biocatalytic potential of extremophiles and extremozymes. Food Technology and Biotechnology, v. 42, n. 4, p. 223-235, 2004.

KAKHKI, A. M.; AMOOZEGAR, M. A.; KHALEDI, E. M. Diversity of hydrolytic enzymes in haloarcheal strains isolated from salt lake. International Journal of Environmental Science and Technology, v. 8, n. 4, p. 705-714, 2011. https://doi.org/10.1007/BF03326255

KHUNT, M. AND PANDHI, N. Moderate halophilic bacterial community in excreta of wild ass (Equus hemions khur). International Journal of Biosciences. v. 1, n. 5, p. 31-37, 2011.

KULKARNI, N.; SHENDYE, A.; RAO, M. Molecular and biotechnological aspects of xylanases. FEMS Microbiology Reviews, v. 23, n. 4, n. 411-456, 1999. https://doi.org/10.1111/j.1574-6976.1999.tb00407.x

MARGESIN, R. AND SCHINNER, F. Potential of halotolerant and halophilic microorganisms for biotechnology. Extremophiles, v. 5, n. 2, p. 73-83, 2001. https://doi.org/10.1007/s007920100184 
MELLADO, E.; SANCHEZ-PORRO, C.; MARTIN, S.; VENTOSA, A. Extracellular hydrolytic enzymes produced by moderately halophilic bacteria. In: Ventosa, A., (ed) Halophilic Microorganisms, SpringerVerlag, Berlin Heidelberg, pp 285-295, 2004.

MORENO, M. L.; PÉREZ, D.; GARCÍA, M. T.; MELLADO, E. Halophilic bacteria as a source of novel hydrolytic enzymes. Life, v. 3, n. 1, p. 38-51, 2013. https://doi.org/10.3390/life3010038

NIEHAUS, F.; BERTOLDO, C.; KAHLER, M.; ANTRANIKIAN, G. Extremophiles as a source of novel enzymes for industrial application. Applied Microbiology and Biotechnology, v. 51, n. 6, p. 711-729, 1999. https://doi.org/10.1007/s002530051456

OREN, A. Diversity of halophilic microorganisms: Environments, phylogeny, and applications. Journal of Industrial Microbiology and Biotechnology, v. 28, n. 1, p. 56-63, 2002.

https://doi.org/10.1038/sj/jim/7000176

PANDEY, A.; NIGAM, P.; SOCCOL, C. R.; BENJAMIN, S.; KRIEGER, N.; SOCCOL V. T. The realm of microbial lipase in biotechnology. Biotechnology and Applied Biochemistry, v. 29, n. 2, p. 119-131, 1999. https://doi.org/10.1111/j.1470-8744.1999.tb00541.x

PANDEY, A.; NIGAM, P.; BENJAMIN, S.; SOCCOL, C. R.; SOCCOL, V. T.; SINGH, D.; MOHAN, R. Advances in microbial amylases. Biotechnology and Applied Biochemistry, v. 31, n. 2, p. 135-152, 2000. https://doi.org/10.1042/BA19990073

RAO, M. B.; TANKSALE, A. M.; GHATGE, M. S.; DESHPANDE, V. V. Molecular and biotechnological aspects of microbial proteases. Microbiology and Molecular Biology Reviews, v. 62, n. 3, p. 597-635, 1998.

RUBEN, D.; GONZALE, E.; ARENAS, C.; VILCHES, E. B.; DE BILLERBECK, M. Selective procedure for isolating microorganisms producing pullulanase and isoamylase. Biotechnology Techniques, v. 7, n. 6. P. 429434, 1993.

ROHBAN, R.; AMOOZEGAR, M. A.; VENTOSA, A. Screening and isolation of halophilic bacteria producing extracellular hydrolyses from Howz Soltan Lake, Iran. Journal of Industrial Microbiology and

Biotechnology, v. 36, n. 3. P. 333-340, 2009. https://doi.org/10.1007/s10295-008-0500-0

SÁNCHEZ-PORRO, C.; MARTIN, S.; MELLADO, E.; VENTOSA, A. Diversity of moderately halophilic bacteria producing extracellular hydrolytic enzymes. Journal of Applied Microbiology, v. 94, n. 2, p. 295300, 2003. https://doi.org/10.1046/j.1365-2672.2003.01834.x

VENTOSA, A.; NIETO, J. J.; OREN, A. Biology of moderately halophilic aerobic bacteria. Microbiology and Molecular Biology Reviews, v. 62, n. 2, p. 504-544, 1998.

WEI, S.; CUI, H.; JIANG, Z.; LIU, H.; HE, H.; FANG, N. Biomineralization processes of calcite induced by bacteria isolated from marine sediments. Brazilian Journal of Microbiology, v. 46, n. 2, p. 455-464. 2015. https://doi.org/10.1590/S1517-838246220140533 